\title{
Development of genome-wide polymorphic microsatellite markers for Trichinella spiralis
}

\author{
Ting-Ting $\mathrm{Li}^{1+}$, Bin Tang ${ }^{1 \dagger}$, Xue Bai ${ }^{1}$, Xue-Lin Wang ${ }^{1}$, Xue-Nong Luo ${ }^{2}$, Hong-Bin Yan ${ }^{2}$, Hong-Fei Zhu ${ }^{3}$, Hong Jia ${ }^{3}$, \\ Xiao-Lei Liu ${ }^{1 *}$ and Ming-Yuan Liu ${ }^{1,4^{*}}$
}

\begin{abstract}
Background: Trichinella nematodes are globally distributed food-borne pathogens, in which Trichinella spiralis is the most common species in China. Microsatellites are a powerful tool in population genetics and phylogeographic analysis. However, only a few microsatellite markers were reported in T. spiralis. Thus, there is a need to develop and validate genome-wide microsatellite markers for T. spiralis.
\end{abstract}

Methods: Microsatellites were selected from shotgun genomic sequences using MlcroSAtellite identification tool (MISA). The identified markers were validated in 12 isolates of T. spiralis in China.

Results: A total of 93,140 microsatellites were identified by MISA from 9267 contigs in T. spiralis genome sequences, in which 16 polymorphic loci were selected for validation by PCR with single larvae from 12 isolates of T. spiralis in China. There were 7-19 alleles per locus (average 11.25 alleles per locus). The observed heterozygosity $\left(H_{0}\right)$ and expected heterozygosity $\left(H_{E}\right)$ ranged from 0.325 to 0.750 and 0.737 to 0.918 , respectively. The polymorphism information content (PIC) ranged from 0.719 to 0.978 (average 0.826 ). Among the 16 loci, markers for 10 loci could be amplified from all 12 international standard strains of Trichinella spp.

Conclusions: Sixteen highly polymorphic markers were selected and validated for T. spiralis. Primary phylogenetic analysis showed that these markers might serve as a useful tool for genetic studies of Trichinella parasites.

Keywords: Trichinella spiralis, Microsatellite, Cross-amplification

\section{Background}

Human trichinellosis is caused by eating raw or undercooked meat infected with Trichinella parasites [1]. Trichinella parasites have a broad geographical distribution on all continents except Antarctica, and can infect $>150$ animal species, including mammals, birds and reptiles [2]. The genus Trichinella contains nine species and three genotypes that can be separated into two clades by the ability to form encapsulated and non-encapsulated larvae [3-5]. There are genetic variations in Trichinella

\footnotetext{
*Correspondence: liuxlei@163.com; liumy@jlu.edu.cn

${ }^{\dagger}$ Ting-Ting Li and Bin Tang contributed equally to this work

1 Key Laboratory of Zoonosis Research, Ministry of Education,

Institute of Zoonosis, College of Veterinary Medicine, Jilin University,

Changchun 130062, Jilin, People's Republic of China

Full list of author information is available at the end of the article
}

spp. based on geographical distributions and host species [6, 7]. In China, Trichinella spp. have been reported in a range of animals, including foxes, bears, wild boar, weasels, raccoon dogs, rats, bamboo rats and civets [8]. Only two Trichinella species (i.e. T. spiralis and T. nativa) have been identified in China [8-12]. However, little is known about the genetic variations among the Trichinella species in China.

Genetic variability in T. spiralis was first reported in 1992, with three allozyme patterns at the loci of glucose 6-phosphate dehydrogenase and glucose phosphate isomerase detected in 61 isolates of T. spiralis from zoogeographical regions [6]. Genetic polymorphisms in T. spiralis were also studied using different molecular tools, such as restriction fragment length polymorphism and single-strand conformational polymorphism

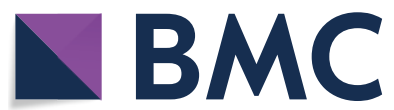

(c) The Author(s) 2020. This article is licensed under a Creative Commons Attribution 4.0 International License, which permits use, sharing, adaptation, distribution and reproduction in any medium or format, as long as you give appropriate credit to the original author(s) and the source, provide a link to the Creative Commons licence, and indicate if changes were made. The images or other third party material in this article are included in the article's Creative Commons licence, unless indicated otherwise in a credit line to the material. If material is not included in the article's Creative Commons licence and your intended use is not permitted by statutory regulation or exceeds the permitted use, you will need to obtain permission directly from the copyright holder. To view a copy of this licence, visit http://creativeco mmons.org/licenses/by/4.0/. The Creative Commons Public Domain Dedication waiver (http://creativecommons.org/publicdomain/ zero/1.0/) applies to the data made available in this article, unless otherwise stated in a credit line to the data. 
(RFLP-SSCP) $[13,14]$, non-isotopic single-strand conformation polymorphism ('cold' SSCP) [15], and deep resequencing of the mitochondrial genomes [16]. Compared with other molecular markers, microsatellites exist throughout the genome. In addition, microsatellites are relatively easy to score, since their gel band patterns could provide unambiguous results. Thus, they have been widely used in genetic diversity, population genetic structure, genome mapping, parentage analysis, population genetics and phylogeography studies [17-19]. However, only a few microsatellites have been reported in $T$. spiralis [12, 20-22]. The present study was aimed to identify and characterize microsatellites in T. spiralis and to obtain polymorphic microsatellite markers for further study.

\section{Methods}

\section{Parasites}

Twelve isolates of T. spiralis were obtained from seven regions in China: five from Tianjin city, two from Yunnan Province, and one each from Heilongjiang, Henan, Hubei, Shaanxi and Tibet, respectively (Fig. 1). All isolates were confirmed as T. spiralis using multiplex PCR method according to Zarlenga et al. [23]. The following 15 international standard Trichinella strains were acquired from the International Trichinella Reference Centre (ITRC; Rome, Italy): T. spiralis (T1, ISS534 and ISS4); T. nativa (T2, ISS70); T. britovi (T3, ISS100); T. pseudospiralis (T4, ISS13, ISS141 and ISS470); T. murrelli (T5, ISS415); Trichinella T6 (ISS34); T. nelsoni (T7, ISS37); Trichinella T8 (ISS124); Trichinella T9 (ISS408); T. papuae (T10, ISS572); T. zimbabwensis (T11, ISS1029); and T. patagoniensis (T12, ISS1826). All isolates and strains were maintained by serial passages in ICR mice. Larvae were recovered from the muscle tissues of infected mice on day 35 post-infection by an artificial digestion method [24], and stored at $-80^{\circ} \mathrm{C}$ until use.

\section{Microsatellite identification and primer design}

All 9267 contigs of $T$. spiralis were retrieved from GenBank database (https://www.ncbi.nlm.nih.gov/nucco re/ABIR00000000) and used to search for microsatellite sequences by MIcroSAtellite Identification Tool (MISA) that was configured with strict minimum motif repeat requirements [25]. The criteria of motifs were that monoto hexanucleotide repeats with a minimum of $12 \mathrm{bp}$ and a minimum of two repeat units. The maximum length of sequence between two simple sequence repeats (SSRs) to register as compound SSR was $100 \mathrm{bp}$ [19]. The number of microsatellites, motif, number of repeats, length of the repeat sequence, repeat type, start and end position of the repeat sequence, and microsatellite sequence, were analyzed using MISA.
Primers flanking the putative microsatellite sequences were designed at the PRIMER3 online server (http:// primer3.ut.ee) [26], using following parameters: optimal primer length $=20 \mathrm{bp}$ (between 18-22 bp); optimal primer $\mathrm{GC}$ content $=50 \%$ (between $40-60 \%$ ); optimal primer melting temperature $=58{ }^{\circ} \mathrm{C}$ (between 55.9$60.1^{\circ} \mathrm{C}$ ); and product size ranged from 150 to $300 \mathrm{bp}$. The melting temperatures between a pair of primer had $<1{ }^{\circ} \mathrm{C}$ difference. The specificity of primer sequences was determined by BLAST searches against the genome of $T$. spiralis (https://www.ncbi.nlm.nih.gov/tools/primer-blast/).

\section{Screening of microsatellites by PCR}

A total of 1000 SSR primer pairs were selected for preliminary screening by PCR using DNA from a pool of $\sim 4000$ muscle larvae $(\sim 350$ larvae from each of the $12 \mathrm{~T}$. spiralis isolates in China). For isolating DNA, all larvae were homogenized in $500 \mu \mathrm{l}$ extraction buffer containing $500 \mathrm{mM} \mathrm{NaCl}, 10 \mathrm{mM}$ Tris-Cl (pH 8.0), $50 \mathrm{mM}$ EDTA $(\mathrm{pH} 8.0), 2 \%(\mathrm{w} / \mathrm{v})$ SDS and $10 \mathrm{mM} \beta$-mercaptoethanol, followed by incubation with $5 \mu \mathrm{l}$ of proteinase $\mathrm{K}(20 \mathrm{mg} /$ $\mathrm{ml}$ ) at $60{ }^{\circ} \mathrm{C}$ for $0.5-2 \mathrm{~h}$, phenol-chloroform extraction $(50: 50 \%, \mathrm{v} / \mathrm{v})$, precipitation with $70 \%$ ethanol, and resuspension in 30-50 $\mu \mathrm{l}$ of sterile water. DNA samples were stored at $-20{ }^{\circ} \mathrm{C}$. PCR reactions were carried out in a final volume of $20 \mu \mathrm{l}$, consisting of $\sim 50 \mathrm{ng}$ of DNA, $2 \mu \mathrm{l}$ of $10 \times$ Ex Taq buffer $\left(20 \mathrm{mM} \mathrm{Mg}^{2+}\right.$ Plus; TaKaRa, Kusatsu, Japan), $1.6 \mu \mathrm{l}$ of dNTP mixture (2.5 mM each), $0.2 \mu \mathrm{l}$ of Ex Taq DNA polymerase $(5 \mathrm{U} / \mu \mathrm{l})$ (TaKaRa), and $0.4 \mu \mathrm{l}$ of each primer $(10 \mathrm{pmol} / \mu \mathrm{l})$. PCR amplifications were performed in a thermal cycler (Applied Biosystems, California, USA) using following program: $98{ }^{\circ} \mathrm{C}$ for $5 \mathrm{~min}$; followed by 35 cycles of $98^{\circ} \mathrm{C}$ for $10 \mathrm{~s}$, a specified annealing temperature for each primer pair for $30 \mathrm{~s}, 72{ }^{\circ} \mathrm{C}$ for $30 \mathrm{~s}$; and a final extension step at $72{ }^{\circ} \mathrm{C}$ for $7 \mathrm{~min}$. PCR products were electrophoresed on $1 \%$ agarose gels, stained with ethidium bromide and visualized under UV illumination. Microsatellite markers producing single bands were selected as candidate loci for further validation.

\section{Verification of microsatellite polymorphism}

Each of the selected primers was validated with 40 single larvae of T. spiralis from seven regions in China. Single larva was digested with proteinase K for DNA extraction using a Tissue and Hair Extraction Kit and a DNA IQ ${ }^{\mathrm{TM}}$ System Extraction Kit (Promega, Madison, USA) with magnetic beads following manufacturer's instructions. DNA was eluted in $25 \mu \mathrm{l}$ of elution buffer. Whole genome amplification was performed using an Illustra ${ }^{\mathrm{TM}}$ Ready$\mathrm{To}^{-G_{0}{ }^{\mathrm{TM}}}$ GenomiPhi V3 DNA Amplification Kit (GE Healthcare, Pittsburgh, USA) to increase the quantity 


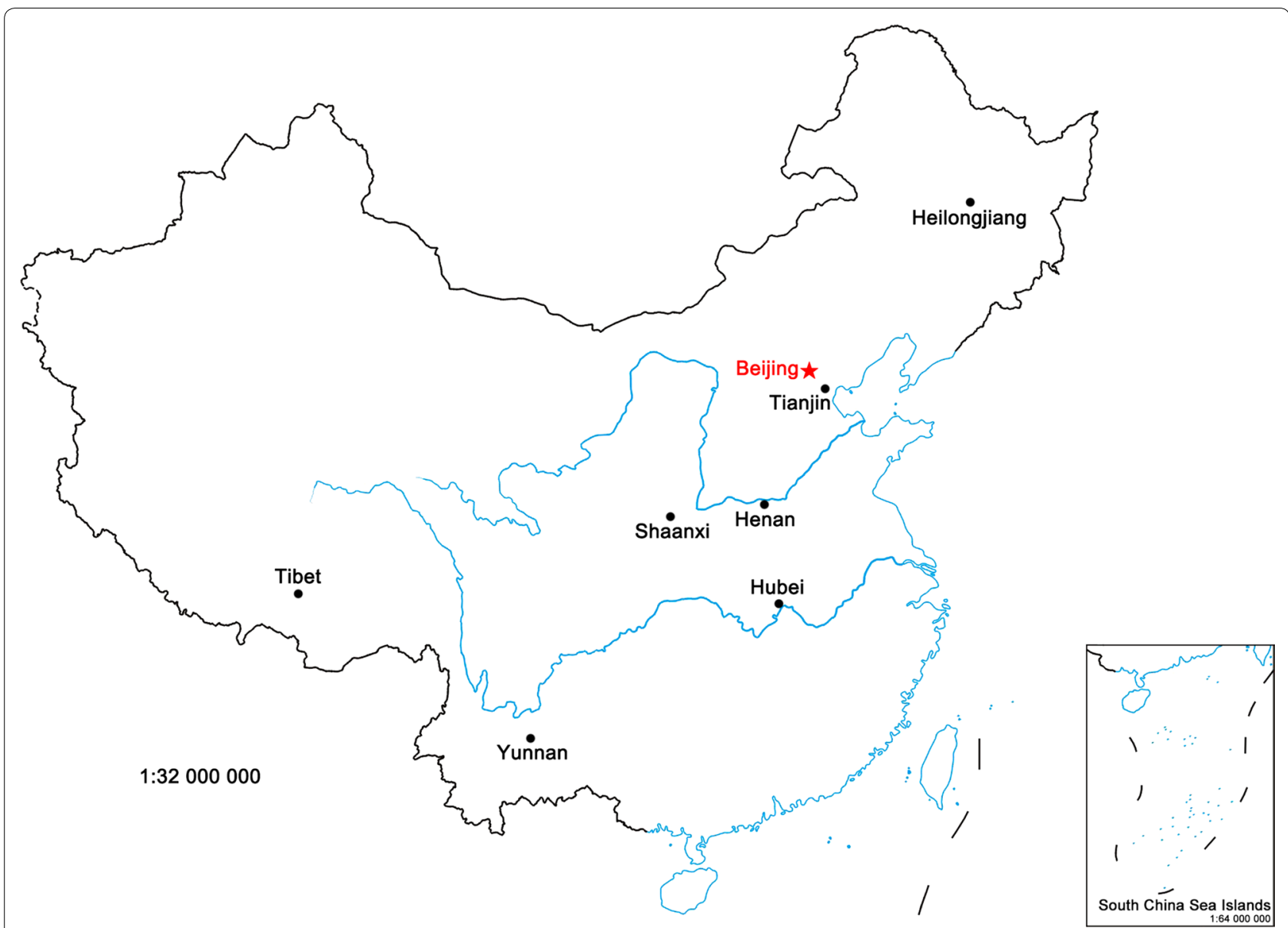

Fig. 1 Distribution of Trichinella spiralis isolates from different geographical regions in China. Twelve isolates of T. spiralis were obtained from seven regions in China: five from Tianjin city; two from Yunnan Province; and one each from Heilongjiang, Henan, Hubei, Shaanxi and Tibet, respectively

of DNA. Concentrations of DNA were measured in a NanoDrop 2000 photometer (Thermo Fisher Scientific, Waltham, USA).

PCR amplifications were performed in a $20 \mu \mathrm{l}$ reaction using a primer mixture which contained three primers: a sequence-specific forward primer with M13-tail at its $5^{\prime}$-end, a sequence-specific reverse primer, and the universal fluorescent-labeled M13 primer (FAM-M13 primer) [27]. A $20 \mu \mathrm{l}$ reaction contained $0.05 \mu \mathrm{M}$ forward primer, $0.25 \mu \mathrm{M}$ reverse primer, $0.2 \mu \mathrm{M}$ FAM-M13 primer, $0.16 \mathrm{mM}$ dNTP, $1 \mathrm{U}$ of Ex Taq DNA polymerase (TaKaRa), and $\sim 50 \mathrm{ng}$ of DNA from a single larva [27]. The PCR program was run as follows: $98{ }^{\circ} \mathrm{C}$ for $5 \mathrm{~min} ; 32$ cycles of $98{ }^{\circ} \mathrm{C}$ for $10 \mathrm{~s}$, an annealing temperature specified for a primer pair for $30 \mathrm{~s}$, and $72{ }^{\circ} \mathrm{C}$ for $30 \mathrm{~s}$; eight additional cycles of $98{ }^{\circ} \mathrm{C}$ for $10 \mathrm{~s}, 53{ }^{\circ} \mathrm{C}$ for $30 \mathrm{~s}$ and $72{ }^{\circ} \mathrm{C}$ for $30 \mathrm{~s}$; a final extension at $72{ }^{\circ} \mathrm{C}$ for $7 \mathrm{~min}$. PCR products were subjected to capillary electrophoresis analysis (CEA) with a 96-capillary 3730XL DNA Analyzer (Applied Biosystems). Data were analyzed with
GeneMapper 4.0 (Applied Biosystems). A negative control with sterile water was included in each PCR run.

Finally, the microsatellite loci with high polymorphism were selected for further validation by PCR using DNA samples isolated from individual larvae from 12 isolates of T. spiralis in China (10 larvae per isolate; total 120 samples). PCR amplification and analysis followed the protocols described above.

\section{Polymorphism analysis}

For each locus, the number of alleles $\left(N_{a}\right)$, the effective number of alleles $\left(N_{e}\right)$, the expected heterozygosity $\left(H_{E}\right)$ and the observed heterozygosity $\left(H_{O}\right)$ per locus were estimated using GENEPOP version 4.2 (http://genep op.curtin.edu.au/) [28]. This same software was used to test the polymorphism information content (PIC) and possible deviations from Hardy-Weinberg equilibrium (HWE) with Bonferroni correction [29]. 


\section{Cross-amplification}

DNA samples were isolated from the 12 Trichinella international standard strains as described in section "Screening of microsatellites by PCR" above. Crossamplifications at selected polymorphic loci were performed and analyzed by a capillary electrophoresis using the same PCR protocols as described in section "Verification of microsatellite polymorphism" above.

\section{Phylogenetic analysis}

The PCR products amplified from 15 international standard strains at the TsMs03 locus were analyzed by $8 \%$ denaturing urea-polyacrylamide gel electrophoresis. The homozygous individuals were selected for sequencing. Multiple sequence alignments of nucleotide sequences at the TsMs03 locus were performed using Clustal Omega (https://www.ebi.ac.uk/Tools/msa/clustalo/) [30]. The phylogenetic tree was inferred by MEGA $X$ using the Neighbor-Joining method with 1000 bootstrap replicates $[31,32]$.

\section{Results}

\section{Abundance and microsatellite characteristics}

A total of 93,140 microsatellites were identified from 9267 contigs of the T. spiralis genome by MISA (Table 1 ). The microsatellite density was 1591 loci per Mb. Among motifs containing mono- to hexanucleotide repeats, the most abundant was hexanucleotides that accounted for $49.51 \%$ of the total, followed by trinucleotide (19.61\%) and tetranucleotide (17.44\%). The di-, penta-, and mononucleotide motifs accounted for $8.77 \%, 3.69 \%$, and $0.98 \%$ of the total motifs, respectively. The significant decrease in abundance of microsatellites was accompanied by the increase in the number of motif repeats. The number of repeating nucleotide sets was two times in $97.81 \%$ of hexanucleotide repeats. Meanwhile the number was three times in $1.81 \%$ of hexanucleotide repeats. For the pentanucleotide repeats, $68.29 \%$ consisted of three repeats, 19.12\% consisted of four repeats, $8.18 \%$ consisted of five repeats, and $1.63 \%$ consisted of six repeats (Fig. 2). The top 20 most frequently classified repeat types were listed in Fig. 3. The most common motifs in each type of repeats were A/T (59.43\%), AT/AT (61.84\%), AAT/ ATT (39.28\%), AAAT/ATTT (37.30\%), AAAAT/ATTTT (18.07\%) and AAAAAT/ATTTTT (10.87\%). The longest repeat was (TATAA) ${ }_{98}$ which belonged to the pentanucleotide group (Table 2).

\section{Polymorphic microsatellite screening}

Among the 1000 microsatellite loci selected for primary screening, 676 loci generated PCR products at expected sizes. A total of 120 loci producing single bright band in gel electrophoresis were selected as candidate loci.
Among them, 47 microsatellite loci were homozygotes, while 57 loci showed low polymorphism. Finally, we selected 16 loci that produced distinct bands among individual larvae originated from different regions in China with high polymorphism for further analysis (Table 3).

\section{Polymorphism analysis}

$N_{a}$ varied from 7 to 19 , and $N_{e}$ ranged from 5.655 to 14.452 (average 8.820) per locus. $H_{O}$ and $H_{E}$ ranged from 0.325 to 0.750 and 0.737 to 0.918 , respectively. PIC ranged from 0.719 to 0.978 (average of 0.826 ). The final set of 16 microsatellite markers were all highly informative (PIC >0.50), and four of the 16 loci showed significant deviations from HWE after Bonferroni correction (Table 4).

\section{Cross-amplification}

Among the final 16 loci, 10 produced PCR amplicons for all tested Trichinella spp. Four (i.e. TsMs01, TsMs04, TsMs10 and TsMs14) obtained PCR products only from the Trichinella spp. with encapsulated larvae. Most of these loci were homozygous in the T. britovi (encapsulated larvae) and species with non-encapsulated larvae (Table 5). In addition, the TsMs07 and TsMs08 loci were amplified from species with encapsulated and non-encapsulated larvae, except for T. pseudospiralis. The average number of amplified alleles in each of the Trichinella spp. ranged from 1.300 (T. papuae and T. zimbabwensis) to 2.938 (Trichinella T9). A maximum of six alleles was observed in Trichinella T9 strain at the TsMs03 locus. Allelic size varied among taxa at a given locus, and one allele was shared by two or three taxa commonly. Trichinella T9 had specific alleles at three loci (i.e. TsMs12, TsMs14 and TsMs16) that were different in allelic size from other Trichinella taxa. None of the alleles at a given locus were shared by all Trichinella spp.

\section{Phylogenetic analysis}

Primary phylogenetic analysis showed that all Trichinella spp. clustered into two clades: encapsulated larvae and non-encapsulated larvae group (Fig. 4). Sister relationship was observed for $T$. spiralis and T. nelsoni in comparison to other species with encapsulated larvae. Trichinella papuae and T. zimbabwensis were more closely related to each other than to T. pseudospiralis.

\section{Discussion}

Microsatellites have been used in genetic diversity and genetic mapping studies in various organisms [33-35], partly because of their high polymorphism and the ability to detect alleles at a given locus in individual organisms [36, 37]. In previous studies, most of microsatellites 
Table 1 Motif statistic of Trichinella spiralis microsatellites

\begin{tabular}{lllll}
\hline Motif & Total counts & Distribution (\%) & Average length & Counts/Mbp \\
\hline Mononucleotide & 912 & 0.98 & 14.28 & 0.013 \\
Dinucleotide & 8166 & 8.77 & 18.71 & 0.152 \\
Trinucleotide & 18,267 & 19.61 & 16.23 & 0.297 \\
Tetranucleotide & 16,241 & 17.44 & 14.25 & 0.231 \\
Pentanucleotide & 3437 & 3.69 & 18.3 & 0.063 \\
Hexanucleotide & 46,117 & 49.51 & 12.16 & 0.561 \\
\hline
\end{tabular}

in T. spiralis were designed based on expressed sequence tag (EST) databases [20-22]. The present study identified 93,140 microsatellites in the $T$. spiralis genomes using MISA, which accounted for $2.25 \%$ of the total genome sequence. The relative abundance of microsatellite sequences was estimated at 1.591 loci per $\mathrm{kb}$ of the $T$. spiralis genomes.

Generally, microsatellites decrease in abundance with increasing repeat length $[38,39]$, and this trend has been observed in many organisms [40]. Previous comparative studies of microsatellites from eukaryotic genomes have found that the composition characteristics and distribution patterns significantly varied by species [39, 41]. Caenorhabditis elegans has a low frequency of microsatellites in its genome, even lower than Saccharomyces cerevisiae and other fungi $[19,42,43]$. In general, eukaryotic genomes are characterized by the prevalence of mononucleotide repeat motifs $[19,44]$. For instance, mononucleotide repeats are the most abundant class of microsatellites in C. elegans [19] and Meloidogyne incognita [45]. However, dinucleotide repeats are the most abundant type of motif in rodents [19] and most dicot plant species [46]. Moreover, trinucleotide repeats are dominant in some algae and fungi species [44, 47], potentially indicating their genomic structural similarity with prokaryotes [48]. In contrast, tetra- to hexanucleotide repeats are less abundant in eukaryotic genomes [49, 50]. Intriguingly, our results suggested a different distribution pattern for T. spiralis: hexa- $>$ tri- $>$ tetra- $>$ di- $>$ penta- $>$ mononucleotide repeats. The repeat frequency of hexanucleotides (49.51\%) was higher than other repeat classes. This may be a characteristic that is unique to $T$. spiralis. It is also possible that the abundance of repeats is influenced by secondary structures and DNA replication [49].

Among mononucleotide repeats, the motif $(\mathrm{A} / \mathrm{T})_{\mathrm{n}}$ is predominant, while $(C / G)_{n}$ repeats are rare $[45,48]$. Our results for the most dominant motif type in mono- to hexanucleotide repeat classes of T. spiralis showed similar

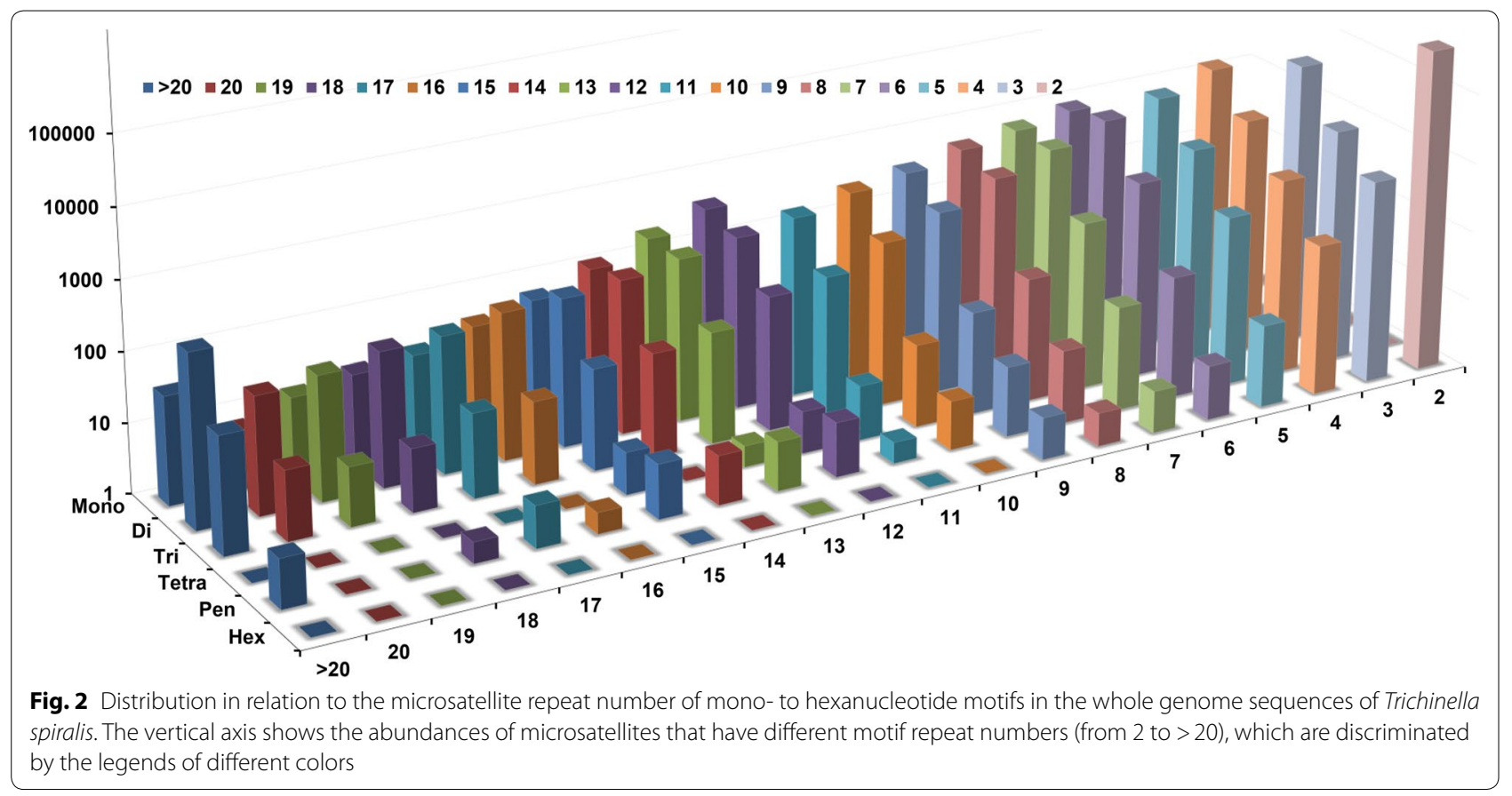




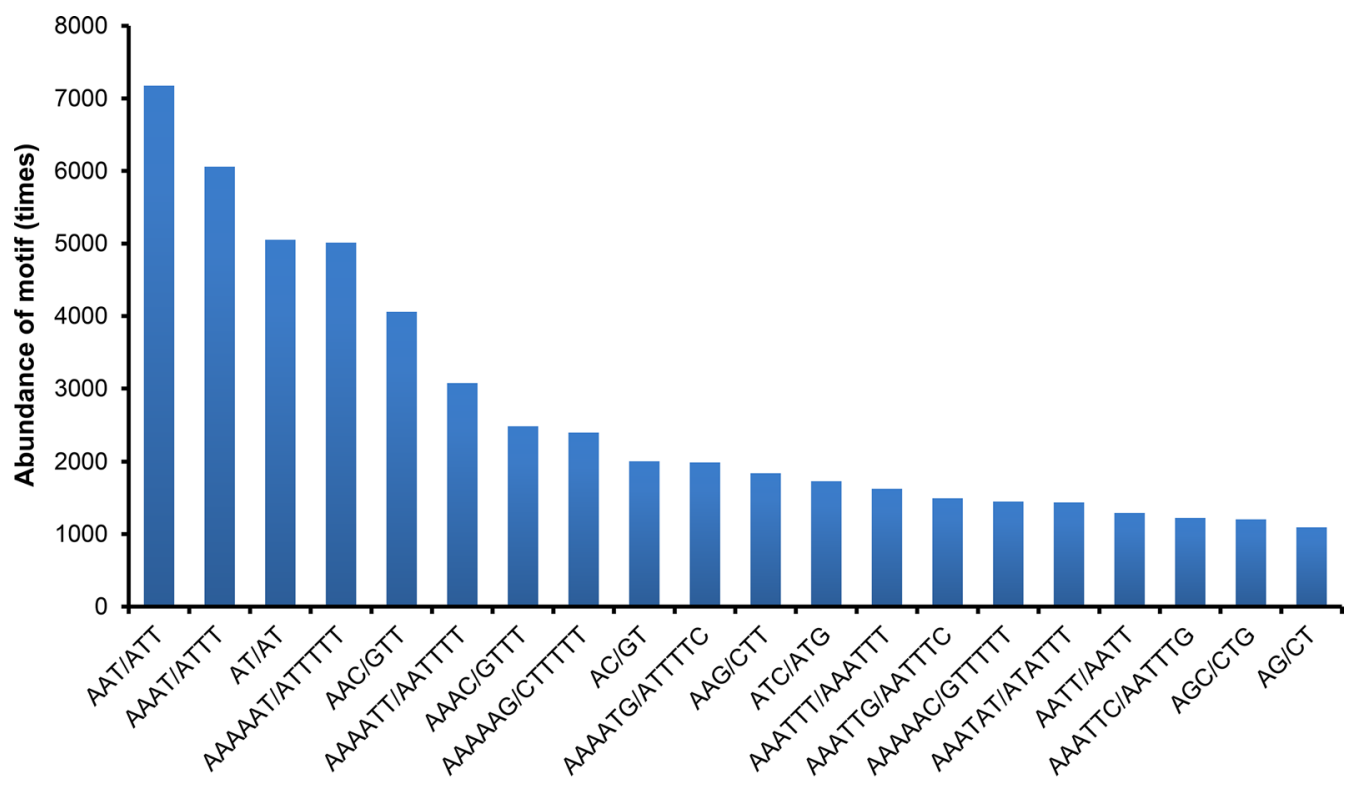

Motif of microsatellites

Fig. 3 The 20 most frequently classified repeat types (considering sequence complementary) in Trichinella spiralis. The most common motifs in each type of repeats were A/T, AT/AT, AAT/ATT, AAAT/ATTT, AAAAT/ATTTT and AAAAAT/ATTTTT

Table 2 Most common and the longest microsatellites of the motifs

\begin{tabular}{|c|c|c|c|c|c|c|c|c|c|c|c|c|}
\hline \multirow[t]{2}{*}{ Repeat } & \multicolumn{2}{|c|}{ Mononucleotide } & \multicolumn{2}{|c|}{ Dinucleotide } & \multicolumn{2}{|c|}{ Trinucleotide } & \multicolumn{2}{|c|}{ Tetranucleotide } & \multicolumn{2}{|l|}{ Pentanucleotide } & \multicolumn{2}{|l|}{ Hexanucleotide } \\
\hline & Motif & $\%$ & Motif & $\%$ & Motif & $\%$ & Motif & $\%$ & Motif & $\%$ & Motif & $\%$ \\
\hline \multirow[t]{6}{*}{ Common } & $A / T$ & 59.43 & AT/AT & 61.84 & AAT/ATT & 39.28 & AAAT/ATTT & 37.30 & AAAAT/ATTTT & 18.07 & AAAAAT/ATTTTTT & 10.87 \\
\hline & $C / G$ & 40.57 & $\mathrm{AC} / \mathrm{GT}$ & 24.53 & $\mathrm{AAC} / \mathrm{GTT}$ & 22.21 & AAAC/GTTT & 15.27 & AAATT/AATTT & 10.53 & AAAATT/AATTTT & 6.67 \\
\hline & & & $\mathrm{AG} / \mathrm{CT}$ & 13.38 & AAG/CTT & 10.06 & AATT/AATT & 7.95 & AATAT/ATATT & 9.72 & AAAAAG/CTTTTT & 5.19 \\
\hline & & & CG/CG & 0.24 & ATC/ATG & 9.46 & AATG/ATTC & 6.13 & AAAAC/GTTTT & 7.97 & AAAATG/ATTTTC & 4.31 \\
\hline & & & & & AGC/CTG & 6.58 & ACAT/ATGT & 4.93 & AATAC/ATTGT & 7.22 & AAATTT/AAATTT & 3.52 \\
\hline & & & & & Other & 12.40 & Other & 28.42 & Other & 46.49 & Other & 69.45 \\
\hline Longest & $(\mathrm{G})_{184}$ & & $(\mathrm{TG})_{54}$ & & $(\text { ATA })_{64}$ & & $(\text { CATA })_{17}$ & & $(\text { TATAA })_{98}$ & & $\begin{array}{l}(\text { AATAGT) } \\
(\text { TGTATA) } \\
(\text { TATATG) } \\
(\text { ATATAC) }\end{array}$ & \\
\hline
\end{tabular}

$(\mathrm{A}+\mathrm{T})$-rich motif patterns, where A/T, AT, AAT, AAAT, AAAAT, and AAAAAT were the predominant repeats. The possible reasons for this $(\mathrm{A}+\mathrm{T})$-rich motif pattern may be as follows: $(\mathrm{A}+\mathrm{T})$-rich motifs can decrease the annealing temperature and accelerate strand separation, and the AT content increases through DNA replication and slippage [49]. Secondly, DNA methylation can generate regions with high mutagenic rates, where the cytidine monophosphate becomes transformed into thymine. This type of mutation results from the deamination of methylation sites, leading to a combination of $(\mathrm{A}+\mathrm{T})$-rich repeats. DNA methylation has been confirmed in the three life-cycle stages of $T$. spiralis, making it the only nematode species known to date with epigenetic modification of its genome [51]. In addition, these repeats may be favored because the order of bases can directly influence chromatin structure, protein coding and gene function [50].

Previous studies have shown that Trichinella spp. are considered to have low intraspecific genetic diversity and genetic differentiation between populations $[6,21$, 52-58]. The unique life-cycle of Trichinella species can often promote sibling inbreeding and reduced population size [58]. Therefore, successful selection of microsatellite 
Table 3 Characteristics of 16 microsatellites and primer sets

\begin{tabular}{|c|c|c|c|c|c|c|}
\hline Name & Primer sequence $\left(5^{\prime}-3^{\prime}\right)$ & Repeat motif & Product size (bp) & Contig/ID & Position & $\operatorname{Tm}\left({ }^{\circ} \mathrm{C}\right)$ \\
\hline TsMs01 & $\begin{array}{l}\text { F: GGGCATATATTACGCATACCG } \\
\text { R: ACGACGAAATGATTCTTGCC }\end{array}$ & $(\mathrm{TG})_{25}$ & $265-297$ & gi316972836 & $40205-40481$ & 58 \\
\hline TsMs02 & $\begin{array}{l}\text { F: GATTGGGCAAAGGATGAATG } \\
\text { R: AAAACGACGGCAAATCAAAC }\end{array}$ & $(\mathrm{TTTG})_{9}$ & $157-177$ & gi316972836 & $18217-18374$ & 58 \\
\hline TsMs03 & $\begin{array}{l}\text { F: TGTTACTTCATGTGGCAGAGTG } \\
\text { R: GCCAACTGGATTTTAATGACAGA }\end{array}$ & $(\text { TAATT })_{17}$ & $221-297$ & gi316972363 & 130723-131001 & 60 \\
\hline TsMs04 & $\begin{array}{l}\text { F: CTAAGGCATCGCTGGTTTTT } \\
\text { R:TGATTGGCTATCAAGCAACG }\end{array}$ & $(\mathrm{ATC})_{11}$ & $246-275$ & gi316973090 & 19425-19675 & 58 \\
\hline TsMs05 & $\begin{array}{l}\text { F: CGACAACTTCAACGACGGTA } \\
\text { R:TCGCTTCATCAGAGGGAACT }\end{array}$ & $(\mathrm{GTTT})_{9}$ & $260-292$ & gi316969813 & $186555-186801$ & 60 \\
\hline TsMs06 & $\begin{array}{l}\text { F: TAATGCTGGTTTGCGCTATG } \\
\text { R: AACTGAGCGGAAATTTTGACA }\end{array}$ & $(\mathrm{TAA})_{10}$ & $210-302$ & gi316973625 & $143441-143668$ & 60 \\
\hline TsMs07 & $\begin{array}{l}\text { F: GGCCGTTTTGAAATGAAAAAT } \\
\text { R: GCGTTGATTCAGCTAAGCGT }\end{array}$ & $(\mathrm{ATA})_{9}$ & $252-276$ & gi316976532 & 119918-120196 & 60 \\
\hline TsMs08 & $\begin{array}{l}\text { F: GGGTGTCGTTGTCATTTGTG } \\
\text { R: GGTGCGTGGAAATTGAAAAT }\end{array}$ & $(\mathrm{TAG})_{11}$ & $259-290$ & gi316978307 & $145640-145883$ & 58 \\
\hline TsMs09 & $\begin{array}{l}\text { F: CCTGCGGTTATTGTTTGCTT } \\
\text { R: AGCCGGAGAGAATATGGGAT }\end{array}$ & $(\mathrm{GTA})_{9}(\mathrm{GTT})_{8}$ & $275-298$ & gi316978154 & $85694-85961$ & 58 \\
\hline TsMs10 & $\begin{array}{l}\text { F: ACAGCCCATATTTTTCGACG } \\
\text { R: CCAATTTTAAGCACATTGCG }\end{array}$ & $\left(\right.$ TAACA $_{6}$ & $212-245$ & gi316979296 & $17474-17750$ & 60 \\
\hline TsMs11 & $\begin{array}{l}\text { F: GGATAGCACGTATTGGCGAT } \\
\text { R:TTCAATGCTTTTCGATGCAG }\end{array}$ & $(\text { ACACAT })_{6}$ & $167-197$ & gi316978262 & $56111-56387$ & 58 \\
\hline TsMs12 & $\begin{array}{l}\text { F:TGGAACAAATGCCATTCAAA } \\
\text { R: CCCTGAGCGCAATGTAAAGT }\end{array}$ & $(\mathrm{AAG})_{11}(\mathrm{ATG})_{5}$ & $210-226$ & gi316969236 & 19887-20088 & 58 \\
\hline TsMs13 & $\begin{array}{l}\text { F: GGTAAATGAGGTTCGCGTTC } \\
\text { R: AGGATGTTATTCGCCCAGAA }\end{array}$ & $(\text { ATAA })_{8}$ & $213-272$ & gi316967561 & 66833-67009 & 60 \\
\hline TsMs14 & $\begin{array}{l}\text { F: TCCTGACCCAGTCCATTGAT } \\
\text { R: AAATCGATAAGCATTTGGCG }\end{array}$ & $(\mathrm{CTT})_{8}$ & $210-226$ & gi316977317 & $111618-111824$ & 58 \\
\hline TsMs15 & $\begin{array}{l}\text { F: CCTACGCGATCAAGTGTTCA } \\
\text { R: CTGCGTTTGTCCTCTGTTCA }\end{array}$ & $(\mathrm{TTTG})_{7}$ & $213-272$ & gi316971889 & $83295-83500$ & 56 \\
\hline TsMs16 & $\begin{array}{l}\text { F: GCCACCAGAGTGGACAAAAT } \\
\text { R: GCGTTGAGTGAAGTGATGGA }\end{array}$ & $(\mathrm{TAT})_{22}$ & $215-245$ & gi316977492 & $66935-67190$ & 60 \\
\hline
\end{tabular}

markers with relatively high abundance and polymorphism might be very difficult. Although the microsatellites of T. spiralis were detected in $12 \%$ of the 1000 EST sequences by La Rosa et al. [21], only seven microsatellite markers were suitable for genetic subgroup analysis. In the present study, 16 microsatellite markers with high polymorphism were selected and identified from 1000 candidate microsatellite loci.

To verify microsatellite markers with high polymorphism, we ranked the informativeness of markers using 120 individuals into highly (PIC $>0.50$ ), reasonably (PIC of $0.25-0.50$ ) and slightly informative ( $\mathrm{PIC}<0.25$ ), as proposed by Botstein et al. [59]. Sixteen markers with high PIC were selected in 12 isolates of T. spiralis in China. The number of alleles per locus were positively correlated with the length of the repeat region, such as the locus TsMs03, which had the highest number of alleles and the longest repeat sequence (TAATT) ${ }_{17}$. Previous studies have shown that long loci have higher mutation rates than short loci $[36,60]$. The HWE describes how allele and genotype frequencies are related. Deviations often occur in the presence of small sample size, inbreeding, or
Table 4 Microsatellite markers and their polymorphism characteristics

\begin{tabular}{llllll}
\hline Locus & $N_{a}$ & $N_{e}$ & $H_{O}$ & $H_{E}$ & PIC \\
\hline TsMs01 & 11 & 7.42 & 0.325 & 0.857 & 0.845 \\
TsMs02 & 11 & 7.923 & 0.675 & 0.785 & 0.719 \\
TsMs03 & 19 & 14.452 & 0.75 & 0.918 & 0.978 \\
TsMs04 & 12 & 9.901 & 0.65 & 0.895 & $0.843^{*}$ \\
TsMs05 & 8 & 6.877 & 0.325 & 0.866 & $0.814^{*}$ \\
TsMs06 & 7 & 5.655 & 0.55 & 0.831 & $0.733^{*}$ \\
TsMs07 & 10 & 7.865 & 0.575 & 0.877 & 0.837 \\
TsMs08 & 8 & 6.667 & 0.525 & 0.813 & 0.754 \\
TsMs09 & 13 & 10.321 & 0.675 & 0.875 & 0.887 \\
TsMs10 & 10 & 7.393 & 0.45 & 0.863 & $0.868^{*}$ \\
TsMs11 & 11 & 8.542 & 0.575 & 0.857 & 0.821 \\
TsMs12 & 16 & 12.279 & 0.475 & 0.924 & 0.815 \\
TsMs13 & 9 & 6.957 & 0.625 & 0.874 & 0.834 \\
TsMs14 & 10 & 8.733 & 0.675 & 0.862 & 0.804 \\
TsMs15 & 8 & 6.641 & 0.575 & 0.737 & 0.736 \\
TsMs16 & 17 & 13.476 & 0.55 & 0.943 & 0.925 \\
Mean & 11.25 & 8.82 & 0.561 & 0.861 & 0.826 \\
\hline
\end{tabular}

Abbreviations: $N_{a^{\prime}}$ observed number of alleles; $N_{e^{\prime}}$ effective number of alleles; $H_{E}$ expected heterozygosity; $H_{O}$, observed heterozygosity; PIC, polymorphism information content

*Significant deviation from HWE after Bonferroni correction 
Table 5 Cross-amplifications at 16 polymorphic loci in Trichinella spp.

\begin{tabular}{|c|c|c|c|c|c|c|c|c|c|c|c|c|}
\hline \multirow[t]{2}{*}{ Locus/taxa } & \multicolumn{2}{|c|}{$\begin{array}{l}\text { T. spiralis } \\
\text { ISS4 }\end{array}$} & \multicolumn{2}{|c|}{$\begin{array}{l}\text { T. nativa } \\
\text { ISS70 }\end{array}$} & \multicolumn{2}{|c|}{$\begin{array}{l}\text { T. britovi } \\
\text { ISS100 }\end{array}$} & \multicolumn{2}{|c|}{$\begin{array}{l}\text { T.pseudospiralis } \\
\text { ISS13 }\end{array}$} & \multicolumn{2}{|c|}{$\begin{array}{l}\text { T. murrelli } \\
\text { ISS415 }\end{array}$} & \multicolumn{2}{|c|}{$\begin{array}{l}\text { Trichinella T6 } \\
\text { ISS34 }\end{array}$} \\
\hline & $N_{a}$ & Size (bp) & $N_{a}$ & Size (bp) & $N_{a}$ & Size (bp) & $N_{a}$ & Size (bp) & $N_{a}$ & Size (bp) & $N_{a}$ & Size (bp) \\
\hline TsMs01 & 2 & $267-279$ & 2 & $265-278$ & 2 & $271-281$ & - & - & 2 & 286-296 & 3 & $265-281$ \\
\hline TsMs02 & 1 & 159 & 1 & 167 & 3 & $167-174$ & 1 & 170 & 1 & 178 & 2 & $165-174$ \\
\hline TsMs03 & 4 & $243-284$ & 2 & $222-248$ & 1 & 222 & 1 & 236 & 4 & $263-302$ & 3 & $222-248$ \\
\hline TsMs04 & 2 & $262-268$ & 1 & 258 & 1 & 261 & - & - & 2 & $264-270$ & 1 & 261 \\
\hline TsMs05 & 1 & 267 & 1 & 279 & 2 & $259-263$ & 2 & 288-292 & 2 & $263-267$ & 1 & 263 \\
\hline TsMs06 & 2 & $237-246$ & 2 & $233-239$ & 1 & 236 & 2 & 283-303 & 2 & $239-248$ & 2 & $236-239$ \\
\hline TsMs07 & 2 & 297-303 & 3 & 294-306 & 1 & 294 & - & - & 2 & 296-302 & 2 & 294-297 \\
\hline TsMs08 & 2 & $262-265$ & 2 & $252-258$ & 1 & 261 & - & - & 2 & $264-267$ & 2 & $252-261$ \\
\hline TsMs09 & 1 & 288 & 2 & 273-291 & 1 & 276 & 1 & 286 & 1 & 288 & 2 & 276-291 \\
\hline TsMs10 & 2 & $283-294$ & 1 & 298 & 1 & 293 & - & - & 2 & 284-294 & 2 & $293-299$ \\
\hline TsMs11 & 2 & 295-301 & 2 & $284-290$ & 2 & 284-291 & 1 & 298 & 3 & 290-302 & 3 & 284-296 \\
\hline TsMs12 & 1 & 215 & 2 & $220-230$ & 1 & 212 & 2 & $216-247$ & 1 & 218 & 2 & $211-226$ \\
\hline TsMs13 & 1 & 193 & 1 & 189 & 2 & $181-185$ & 1 & 213 & 1 & 185 & 1 & 189 \\
\hline TsMs14 & 1 & 224 & 2 & $210-222$ & 1 & 219 & - & - & 1 & 226 & 3 & $210-220$ \\
\hline TsMs15 & 1 & 226 & 1 & 213 & 1 & 213 & 1 & 220 & 2 & $213-217$ & 1 & 217 \\
\hline TsMs16 & 3 & $264-270$ & 1 & 231 & 3 & 190-234 & 2 & 195-203 & 2 & $190-265$ & 3 & $190-231$ \\
\hline \multirow[t]{2}{*}{ Locus/taxa } & \multicolumn{2}{|c|}{$\begin{array}{l}\text { T. nelsoni } \\
\text { ISS37 }\end{array}$} & \multicolumn{2}{|c|}{$\begin{array}{l}\text { Trichinella T8 } \\
\text { ISS124 }\end{array}$} & \multicolumn{2}{|c|}{$\begin{array}{l}\text { Trichinella T9 } \\
\text { ISS408 }\end{array}$} & \multicolumn{2}{|c|}{$\begin{array}{l}\text { T.papuae } \\
\text { ISS572 }\end{array}$} & \multicolumn{2}{|c|}{$\begin{array}{l}\text { T.zimbabwensis } \\
\text { ISS1029 }\end{array}$} & \multicolumn{2}{|c|}{$\begin{array}{l}\text { T.patagoniensis } \\
\text { ISS1826 }\end{array}$} \\
\hline & $N_{a}$ & Size (bp) & $N_{a}$ & Size (bp) & $N_{a}$ & Size (bp) & $N_{a}$ & Size (bp) & $N_{a}$ & Size (bp) & $N_{a}$ & Size (bp) \\
\hline TsMs01 & 3 & $265-302$ & 3 & $265-302$ & 3 & 269-289 & - & - & - & - & 2 & $286-296$ \\
\hline TsMs02 & 3 & 158-179 & 2 & 158-165 & 4 & 158-175 & 2 & $158-170$ & 1 & 158 & 1 & 178 \\
\hline TsMs03 & 5 & $222-267$ & 5 & $222-258$ & 6 & $222-252$ & 2 & $241-247$ & 1 & 241 & 4 & $262-301$ \\
\hline TsMs04 & 3 & $258-267$ & 2 & $247-261$ & 3 & $255-261$ & - & - & - & - & 2 & $264-270$ \\
\hline TsMs05 & 1 & 259 & 1 & 263 & 1 & 259 & 1 & 272 & 1 & 276 & 2 & $267-271$ \\
\hline TsMs06 & 2 & $236-239$ & 2 & $236-242$ & 2 & $236-242$ & 1 & 225 & 2 & $224-256$ & 3 & 239-248 \\
\hline TsMs07 & 3 & $285-306$ & 2 & 288-294 & 2 & 288-294 & 1 & 285 & 2 & $296-302$ & 2 & 284-293 \\
\hline TsMs08 & 3 & $252-261$ & 3 & $252-261$ & 3 & $255-264$ & 2 & $252-258$ & 2 & $261-264$ & 2 & $264-267$ \\
\hline TsMs09 & 2 & $273-282$ & 3 & $270-288$ & 2 & $273-282$ & 1 & 280 & 1 & 272 & 1 & 288 \\
\hline TsMs10 & 3 & 284-298 & 3 & $275-298$ & 4 & 284-304 & - & - & - & - & 2 & 284-293 \\
\hline TsMs11 & 4 & $281-296$ & 4 & $284-297$ & 4 & 278-288 & 2 & $286-296$ & 2 & $286-296$ & 2 & 296-302 \\
\hline TsMs12 & 3 & $215-237$ & 3 & $211-242$ & 4 & $215-240$ & 1 & 217 & 1 & 248 & 1 & 218 \\
\hline TsMs13 & 1 & 177 & 1 & 177 & 1 & 185 & 1 & 207 & 1 & 207 & 1 & 185 \\
\hline TsMs14 & 2 & $210-220$ & 2 & $210-220$ & 2 & $214-220$ & - & - & - & - & 1 & 226 \\
\hline TsMs15 & 1 & 225 & 1 & 217 & 1 & 213 & 1 & 219 & 1 & 210 & 1 & 224 \\
\hline TsMs16 & 2 & 190-222 & 3 & $190-234$ & 5 & $190-245$ & 1 & 191 & 2 & 199-203 & 2 & $190-265$ \\
\hline
\end{tabular}

Abbreviation: $N_{a}$, the number of alleles

the effects of population subdivision [61]. Unfortunately, however, four microsatellite sites in tested populations deviated significantly from HWE after Bonferroni correction $(P<0.003)$ [62]. In addition, $H_{O}$ was much lower than $H_{E}$ in these 16 loci, which led to the observation of limited polymorphism to some extent.

Zarlenga et al. [63] found that T. spiralis diverged early in the genus Trichinella. An analysis of population variability used nine microsatellite markers and observed more allelic richness among eight isolates originating in Asia compared to the remaining isolates from Europe, North Africa, and North and South America, suggested that $T$. spiralis populations are more diverse in East Asia, where pigs were first domesticated [20]. Hence, in this study, we developed microsatellite loci and selected the ones with high 


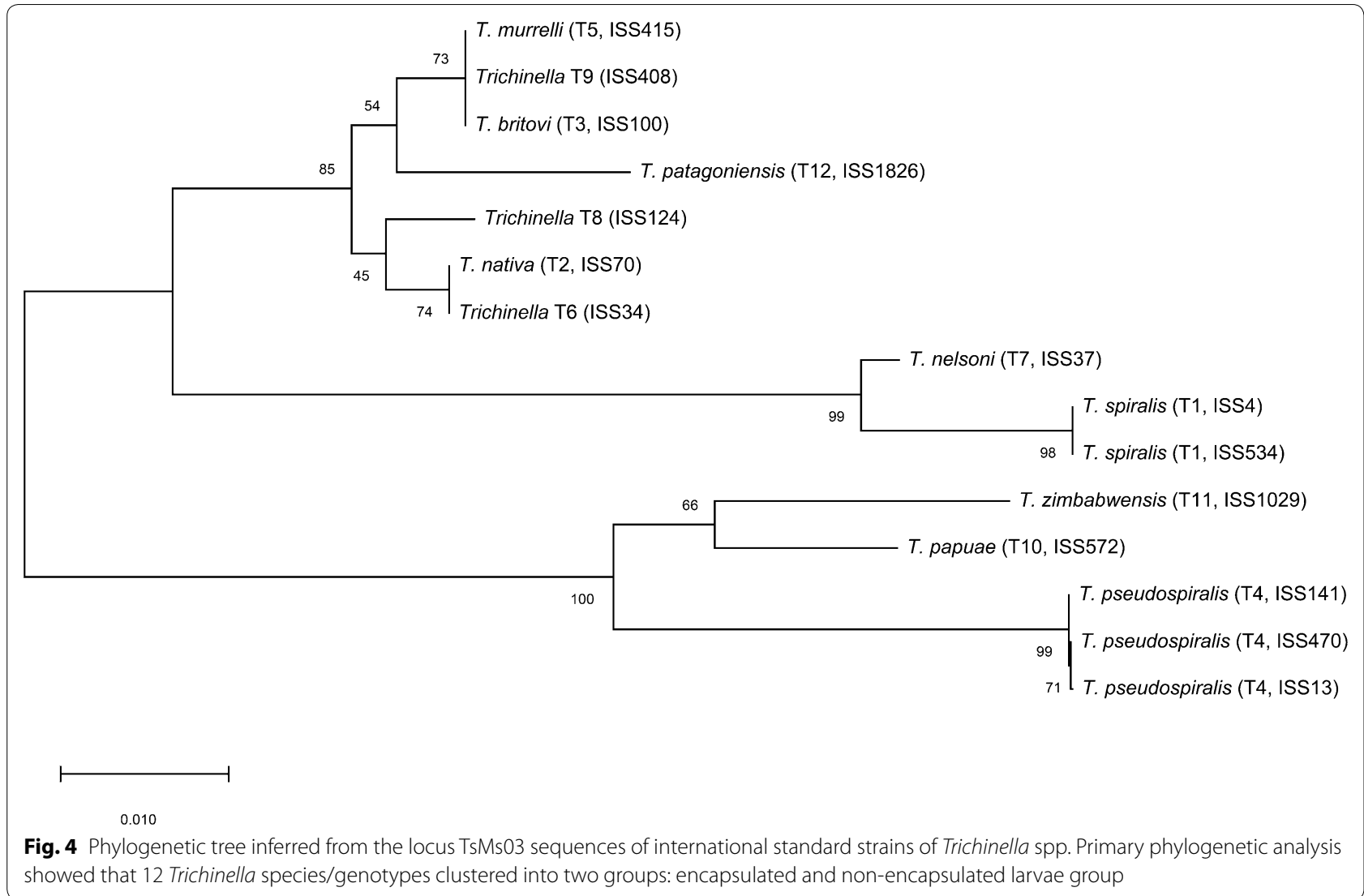

polymorphism in 12 isolates of T. spiralis in China. The flanking sequences of the selected loci were relatively conserved in other Trichinella spp. Thus, ten of the 16 loci were amplified successfully in all 12 Trichinella spp. Therefore, the microsatellite loci developed in this study are good candidate loci to study the genetic variation and structure of Trichinella spp. beyond T. spiralis. Two loci, TsMs07 and TsMs08, were successfully amplified from all Trichinella spp., except for T. pseudospiralis. Recent studies have indicated that all five geographical isolates of $T$. pseudospiralis had one geographical origin that might diverge from T. papuae and T. zimbabwensis. Taken together, our results were consistent with other studies that T. papuae and T. zimbabwensis appeared to be basal in the group of species with non-encapsulated larvae and $T$. pseudospiralis the most recently evolved. The microsatellite analyses confirmed relationships among Trichinella spp. with non-encapsulated larvae, showing the utility of the new markers for investigating distantly related species within the genus [64].

\section{Conclusions}

We reported the identification of microsatellite sequences from the genome sequence data of $T$. spiralis with MISA. Among them, 16 microsatellites with high polymorphisms among 12 isolates of $T$. spiralis from various geographical regions in China were identified, and 10 microsatellites could be amplified successfully from all 12 Trichinella spp. The primary phylogenetic analysis suggested that the newly selected microsatellite markers could be applied to the analysis of genetic relationship of Trichinella spp. These microsatellite markers might serve as an important resource for the further study of Trichinella spp.

\section{Abbreviations}

MISA: MIcroSAtellite Identification Tool; $H_{0}$ : Observed heterozygosity; $H_{E}$ : Expected heterozygosity; PIC: Polymorphism information content; RFLP: Restriction fragment length polymorphism; SSCP: Single-strand conformation polymorphism; SSR: Simple sequence repeat; CEA: Capillary electrophoresis analysis; $N_{a}$ : Number of alleles; $N_{e}$ : Effective number of alleles; HWE: HardyWeinberg equilibrium; EST: Expressed sequence tag.

Acknowledgements Not applicable. 


\section{Authors' contributions}

The study was conceived and designed by MYL and XLL. TTL and BT performed the experiments. XB, XNL and HBY analyzed the data. TTL and XLW wrote the manuscript, $\mathrm{HFZ}$ and $\mathrm{HJ}$ improved the manuscript. All authors read and approved the final manuscript.

\section{Funding}

This study was supported by The National Key Research and Development Program of China (2017YFD0501300), the National Natural Science Foundation of China (31520103916, 31872467), Guangdong Innovative and Entrepreneurial Research Team Program (No. 2014ZT05S123) and Program for JLU Science and Technology Innovative Research Team.

\section{Availability of data and materials}

The datasets supporting the findings of this article are included within the article.

\section{Ethics approval and consent to participate}

All mice were handled strictly in accordance with the Animal Ethics Procedures and Guidelines of the People's Republic of China. The protocol was approved by the Institutional Animal Care and Use Committee of Jilin University (Protocol \# 20170318).

\section{Consent for publication}

Not applicable.

\section{Competing interests}

The authors declare that they have no competing interests.

\section{Author details}

${ }^{1}$ Key Laboratory of Zoonosis Research, Ministry of Education, Institute of Zoonosis, College of Veterinary Medicine, Jilin University, Changchun 130062, Jilin, People's Republic of China. ${ }^{2}$ State Key Laboratory of Veterinary Etiological Biology, Key Laboratory of Veterinary Parasitology of Gansu Province, Lanzhou Veterinary Research Institute, CAAS, Lanzhou 730046, Gansu, People's Republic of China. ${ }^{3}$ Institute of Animal Sciences, Chinese Academy of Agricultural Sciences, Beijing 100193, People's Republic of China. ${ }^{4}$ Jiangsu Co-innovation Center for Prevention and Control of Important Animal Infectious Diseases and Zoonoses, Yangzhou, Jiangsu, People's Republic of China.

Received: 31 October 2019 Accepted: 3 February 2020 Published online: 11 February 2020

\section{References}

1. Pozio E, Zarlenga DS. New pieces of the Trichinella puzzle. Int J Parasitol. 2013;43:983-97.

2. Gottstein B, Pozio E, Nockler K. Epidemiology, diagnosis, treatment, and control of trichinellosis. Clin Microbiol Rev. 2009:22:127-45.

3. Pozio E, La Rosa G, Murrell KD, Lichtenfels JR. Taxonomic revision of the genus Trichinella. J Parasitol. 1992;78:654-9.

4. Murrell KD, Lichtenfels RJ, Zarlenga DS, Pozio E. The systematics of the genus Trichinella with a key to species. Vet Parasitol. 2000;93:293-307.

5. Pozio E, Zarlenga DS. Recent advances on the taxonomy, systematics and epidemiology of Trichinella. Int J Parasitol. 2005;35:1191-204.

6. La Rosa G, Pozio E, Rossi P, Murrell KD. Allozyme analysis of Trichinella isolates from various host species and geographical regions. J Parasitol. 1992;78:641-6.

7. Pozio E. Factors affecting the flow among domestic, synanthropic and sylvatic cycles of Trichinella. Vet Parasitol. 2000;93:241-62.

8. Wang ZQ, Cui J, Shen LJ. The epidemiology of animal trichinellosis in China. Vet J. 2007;173:391-8.

9. Liu MY, Zhu XP, Xu KC, Lu Q, Boireau P. Biological and genetic characteristics of two Trichinella isolates in China; comparison with European species. Parasite. 2001;8(Suppl. 2):S34-8.

10. Gasser RB, Zhu XQ, Monti JR, Dou L, Cai X, Pozio E. PCR-SSCP of rDNA for the identification of Trichinella isolates from mainland China. Mol Cell Probes. 1998;12:27-34.
11. Liu M, Boireau P. Trichinellosis in China: epidemiology and control. Trends Parasitol. 2002;18:553-6.

12. Fu BQ, Liu MY, Yao CY, Li WH, Li YG, Wang YH, et al. Species identification of Trichinella isolates from China. Vet Parasitol. 2009;159:214-7.

13. Wu Z, Nagano I, Pozio E, Takahashi Y. Polymerase chain reaction restriction fragment length polymorphism (PCR-RFLP) for the identification of Trichinella isolates. Parasitology. 1999:118:211-8.

14. Wu Z, Nakada T, Nagano I, Takahashi Y. DNA fingerprints of Trichinella as revealed by restriction fragment length polymorphism and singlestrand conformational polymorphism (RFLP-SSCP). Mol Cell Probes. 2000;14:291-7.

15. Gasser RB, Hu M, El-Osta YA, Zarlenga DS, Pozio E. Genetic analysis of Trichinella populations by'cold' single-strand conformation polymorphism analysis. Vet Parasitol. 2005;132:23-6.

16. Webb KM, Rosenthal BM. Deep resequencing of Trichinella spiralis reveals previously un-described single nucleotide polymorphisms and intraisolate variation within the mitochondrial genome. Infect Genet Evol. 2010:10:304-10.

17. Guichoux E, Lagache L, Wagner S, Chaumeil P, Leger P, Lepais $O$, et al. Current trends in microsatellite genotyping. Mol Ecol Resour. 2011;11:591-611.

18. Hodel RG, Segovia-Salcedo MC, Landis JB, Crowl AA, Sun M, Liu X, et al. The report of my death was an exaggeration: a review for researchers using microsatellites in the 21st century. Appl Plant Sci. 2016;4:1600025.

19. Toth G, Gaspari Z, Jurka J. Microsatellites in different eukaryotic genomes: survey and analysis. Genome Res. 2000;10:967-81.

20. Rosenthal BM, LaRosa G, Zarlenga D, Dunams D, Chunyu Y, Mingyuan L et al. Human dispersal of Trichinella spiralis in domesticated pigs. Infect Genet Evol. 2008;8:799-805.

21. La Rosa G, Marucci G, Rosenthal BM, Pozio E. Development of a single larva microsatellite analysis to investigate the population structure of Trichinella spiralis. Infect Genet Evol. 2012;12:369-76.

22. Wang ZQ, Li LZ, Jiang P, Liu LN, Cui J. Molecular identification and phylogenetic analysis of Trichinella isolates from different provinces in mainland China. Parasitol Res. 2012;110:753-7.

23. Zarlenga DS, Chute MB, Martin A, Kapel CM. A multiplex PCR for unequivocal differentiation of all encapsulated and non-encapsulated genotypes of Trichinella. Int J Parasitol. 1999:29:1859-67.

24. Wu XP, Fu BQ, Wang XL, Yu L, Yu SY, Deng HK, et al. Identification of antigenic genes in Trichinella spiralis by immunoscreening of cDNA libraries. Vet Parasitol. 2009;159:272-5.

25. Thiel T, Michalek W, Varshney RK, Graner A. Exploiting EST databases for the development and characterization of gene-derived SSR-markers in barley (Hordeum vulgare L.). Theor Appl Genet. 2003;106:411-22.

26. Untergasser A, Cutcutache I, Koressaar T, Ye J, Faircloth BC, Remm M, et al. Primer3 - new capabilities and interfaces. Nucleic Acids Res. 2012;40:e115.

27. Schuelke M. An economic method for the fluorescent labeling of PCR fragments. Nat Biotechnol. 2000;18:233-4.

28. Nei M. Estimation of average heterozygosity and genetic distance from a small number of individuals. Genetics. 1978:89:583-90.

29. Rice WR. Analyzing tables of statistical tests. Evolution. 1989;43:223-5.

30. Sievers F, Wilm A, Dineen D, Gibson TJ, Karplus K, Li W, et al. Fast, scalable generation of high-quality protein multiple sequence alignments using Clustal Omega. Mol Syst Biol. 2011;7:539.

31. Kumar S, Nei M, Dudley J, Tamura K. MEGA: a biologist-centric software for evolutionary analysis of DNA and protein sequences. Brief Bioinform. 2008;9:299-306.

32. Tamura K, Dudley J, Nei M, Kumar S. MEGA4: Molecular evolutionary genetics analysis (MEGA) software version 4.0. Mol Biol Evol. 2007;24:1596-9.

33. Gower CM, Gabrielli AF, Sacko M, Dembele R, Golan R, Emery AM, et al. Population genetics of Schistosoma haematobium: development of novel microsatellite markers and their application to schistosomiasis control in Mali. Parasitology. 2011;138:978-94.

34. Laoprom N, Sithithaworn P, Ando K, Sithithaworn J, Wongkham S, Laha T, et al. Microsatellite loci in the carcinogenic liver fluke, Opisthorchis viverrini and their application as population genetic markers. Infect Genet Evol. 2010;10:146-53. 
35. Shrivastava J, Barker GC, Johansen MV, Xiaonong Z, Aligui GD, McGarvey ST, et al. Isolation and characterization of polymorphic DNA microsatellite markers from Schistosoma japonicum. Mol Ecol Notes. 2003;3:406-8.

36. Ellegren $\mathrm{H}$. Heterogeneous mutation processes in human microsatellite DNA sequences. Nat Genet. 2000;24:400-2.

37. Selkoe KA, Toonen RJ. Microsatellites for ecologists: a practical guide to using and evaluating microsatellite markers. Ecol Lett. 2006;9:615-29.

38. Temnykh S, DeClerck G, Lukashova A, Lipovich L, Cartinhour S, McCouch S. Computational and experimental analysis of microsatellites in rice (Oryza sativa L.): frequency, length variation, transposon associations, and genetic marker potential. Genome Res. 2001;11:1441-52.

39. Grover A, Aishwarya V, Sharma PC. Biased distribution of microsatellite motifs in the rice genome. Mol Genet Genomics. 2007;277:469-80.

40. Karaoglu H, Lee CM, Meyer W. Survey of simple sequence repeats in completed fungal genomes. Mol Biol Evol. 2005;22:639-49.

41. Sonah H, Deshmukh RK, Sharma A, Singh VP, Gupta DK, Gacche RN, et al. Genome-wide distribution and organization of microsatellites in plants: an insight into marker development in Brachypodium. PLoS ONE. 2011;6:e21298.

42. Katti MV, Ranjekar PK, Gupta VS. Differential distribution of simple sequence repeats in eukaryotic genome sequences. Mol Biol Evol. 2001;18:1161-7.

43. Astolfi P, Bellizzi D, Sgaramella V. Frequency and coverage of trinucleotide repeats in eukaryotes. Gene. 2003;317:117-25.

44. Sharma PC, Grover A, Kahl G. Mining microsatellites in eukaryotic genomes. Trends Biotechnol. 2007;25:490-8.

45. Castagnone-Sereno P, Danchin EG, Deleury E, Guillemaud T, Malausa T, Abad P. Genome-wide survey and analysis of microsatellites in nematodes, with a focus on the plant-parasitic species Meloidogyne incognita. BMC Genomics. 2010;11:598.

46. Kumpatla SP, Mukhopadhyay S. Mining and survey of simple sequence repeats in expressed sequence tags of dicotyledonous species. Genome. 2005:48:985-98.

47. Kim TS, Booth JG, Gauch HG Jr, Sun Q, Park J, Lee YH, et al. Simple sequence repeats in Neurospora crassa: distribution, polymorphism and evolutionary inference. BMC Genomics. 2008;9:31.

48. Qi WH, Jiang XM, Du LM, Xiao GS, Hu TZ, Yue BS, et al. Genome-wide survey and analysis of microsatellite sequences in bovid species. PLoS ONE. 2015;10:e0133667

49. Subramanian S, Mishra RK, Singh L. Genome-wide analysis of microsatellite repeats in humans: their abundance and density in specific genomic regions. Genome Biol. 2003:4:R13.

50. Xu Y, Li W, Hu Z, Zeng T, Shen Y, Liu S, et al. Genome-wide mining of perfect microsatellites and tetranucleotide orthologous microsatellites estimates in six primate species. Gene. 2018;643:124-32.

51. Gao F, Liu XL, Wu XP, Wang XL, Gong DS, Lu HL, et al. Differential DNA methylation in discrete developmental stages of the parasitic nematode Trichinella spiralis. Genome Biol. 2012;13:R100.
52. Dunams-Morel DB, Reichard MV, Torretti L, Zarlenga DS, Rosenthal BM. Discernible but limited introgression has occurred where Trichinella nativa and the T6 genotype occur in sympatry. Infect Genet Evol. 2012;12:530-8

53. Dame JB, Murrell KD, Worley DE, Schad GA. Trichinella spiralis: genetic evidence for synanthropic subspecies in sylvatic hosts. Exp Parasitol. 1987:64:195-203.

54. La Rosa G, Pozio E, Rossi P. Biochemical resolution of European and African isolates of Trichinella nelsoni Britov and Boev, 1972. Parasitol Res. 1991;77:173-6.

55. La Rosa G, Pozio E. Molecular investigation of African isolates of Trichinella reveals genetic polymorphism in Trichinella nelsoni. Int J Parasitol. 2000;30(5):663-7.

56. La Rosa G, Marucci G, Zarlenga DS, Pozio E. Trichinella pseudospiralis populations of the Palearctic region and their relationship with populations of the Nearctic and Australian regions. Int J Parasitol. 2001;31:297-305.

57. La Rosa G, Marucci G, Zarlenga DS, Casulli A, Zarnke RL, Pozio E. Molecular identification of natural hybrids between Trichinella nativa and Trichinella T6 provides evidence of gene flow and ongoing genetic divergence. Int J Parasitol. 2003:33:209-16.

58. Cole R, Viney M. The population genetics of parasitic nematodes of wild animals. Parasit Vectors. 2018;11:590.

59. Botstein D, White RL, Skolnick M, Davis RW. Construction of a genetic linkage map in man using restriction fragment length polymorphisms. Am J Hum Genet. 1980;32:314-31.

60. Schlotterer C. Evolutionary dynamics of microsatellite DNA. Chromosoma. 2000:109:365-71.

61. Lachance J, Tishkoff SA. SNP ascertainment bias in population genetic analyses: why it is important, and how to correct it. Bioessays. 2013;35:780-6.

62. Groenewald CW, Born C, Chown SL, van Vuuren BJ. Development of a microsatellite library for the flightless moth Pringleophaga marioni Viette (Lepidoptera: Tineidae). Conserv Genet Resour. 2011;3:291-4.

63. Zarlenga DS, Rosenthal BM, La Rosa G, Pozio E, Hoberg EP. Post-Miocene expansion, colonization, and host switching drove speciation among extant nematodes of the archaic genus Trichinella. Proc Natl Acad Sci USA. 2006;103:7354-9.

64. Korhonen PK, Pozio E, La Rosa G, Chang BC, Koehler AV, Hoberg EP, et al. Phylogenomic and biogeographic reconstruction of the Trichinella complex. Nat Commun. 2016;7:10513.

\section{Publisher's Note}

Springer Nature remains neutral with regard to jurisdictional claims in published maps and institutional affiliations.

Ready to submit your research? Choose BMC and benefit from

- fast, convenient online submission

- thorough peer review by experienced researchers in your field

- rapid publication on acceptance

- support for research data, including large and complex data types

- gold Open Access which fosters wider collaboration and increased citations

- maximum visibility for your research: over 100M website views per year

At $B M C$, research is always in progress.

Learn more biomedcentral.com/submissions 